\title{
Advocacy Coalition in The Arrangement of The Coastal Slum Area of Untia in Makassar
}

\author{
Zaldi Rusnaedy ${ }^{1}$, Almuhajir Haris ${ }^{2}$ \\ ${ }^{1}$ Universitas Pancasakti Makassar, Jl Andi Mangerangi No 91 Makassar, Indonesia \\ 2Universitas Pancasakti Makassar, Jl Andi Mangerangi No 91 Makassar, Indonesia \\ Corresponding Author: zaldi.rusnaedy.s@unpacti.ac.id \\ doi http://dx.doi.org/10.18196/igpp.811344 \\ Article Info
}

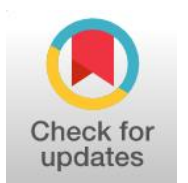

Article History;

Received:

2020-09-06

Revised:

2020-10-28

Accepted:

2021-02-18

\begin{abstract}
The arrangement of the slum settlement area is still a problem faced by the Makassar City Government. There are 740.10 hectares of slum areas in Makassar City, one of which is the Untia coast. This study aimed to analyze the advocacy coalition in slum area management. The research method used was a qualitative method. The results showed that at the beginning of 2019, Untia had become a light slum area from the previous heavy slum. This happened because Untia received many programs from the government for a relatively long time. This activity was a collaborative activity of several government institutions and Kotaku government agencies that are members of the Team Work. Therefore, Untia is still in the category of a slum area, not because of a lack of assistance from the government, but rather because the programs implemented are not integrated. So, the result was that the settlements that receive the program only come out of the slum indicator partially. In addition, the institutions involved in the Team Work often overlap programs due to a lack of face-to-face communications.
\end{abstract}

Keyword: Advocacy Coalition; Collective Action; Settlement Arrangement; Slums.

\section{INTRODUCTION}

One of the big problems faced by developing countries today was the growth and concentration of the population in big cities. Currently, half of the world's population lives in urban areas (Peters \& Pierre, 2012; UN-DESA, 2014). As a result, the unstoppable growth of the population in urban areas has an impact on the growth of dense slum areas (Andini, 2013). Slum areas exist as a consequence of the distance between urban development and the welfare of people who feel excluded (Prianto \& Amalia, 2019). The economic conditions of low-income people have resulted in the inability to build or rent proper housing. The community has no other choice but to live in slum areas to survive in the city by neglecting the physical conditions of the environment, health, and other social conditions.

Housing and slum settlements that are less integrated, lack of direction and neglect of basic facilities and infrastructure, such as sanitation, availability of clean water, waste management systems and sewerage tend to degrade environmental conditions. Although slum areas are not desirable, their existence was difficult to avoid (Mardhanie, 2013). Therefore, to organize slum areas, it was necessary to make comprehensive efforts involving many aspects and stakeholders. This would be a trigger for related stakeholders to solve slum problems and as a form of stimulation to realize a Slum Free Indonesia in 2020 (Prianto \& Amalia, 2019).

The trend of population growth in urban areas needs the attention of all parties, especially the government. This was because slum settlements would have several negative impacts on social conditions. First, the trend of population growth in urban areas has the potential to lead to the big bang of urban poverty. Second, dense urban slum areas have the potential to breed criminal behavior (Andini, 2013). However, the arrangement of urban slum areas was faced with 
several obstacles, one of which was related to the understanding of proper settlement standards. In addition, the functional factors of the settlement were also related to the social, economic, cultural, technological, ecological, and even political dimensions (Suprijanto, 2005).

Problems related to social aspects that were identified by the Research and Development Center for Socio-Economics in the Settlement Sector are related to the inadequate role, institutional capacity, and management of the government (city) and the community related to the slum area management program. Communication between the city government and the community had not been institutionalized optimally, both in structure and function. The unclear concept and strategy of implementing the programs of each agency and private sector related to slum area arrangement was also the source of slums in many cities in Indonesia (Heston \& Yusuf A, 2013).

Some of the problems faced by slum areas are like some previous studies: housing conditions that are not suitable for habitation (Bartz, 2001; Nakamura, 2014, 2017; Omole, 2010), health conditions of people who are prone to disease (Bobhate, 2011; Gladstone et al., 2009; Kulkarni et al., 2012; Oli et al., 2013; Sengupta et al., 2010; Vinod et al., 2011), poor sanitation and difficulty accessing safe clean water (Adubofour et al., 2013; Astuti, 2016; Kandusu et al., 2019; Katukiza et al., 2010, 2012; Siregar, 2010; Van Dijk et al., 2014). The socio-economic conditions of people who live in slum settlements have a terrible domino effect on their stage, occupation, health and various other aspects of life. This condition makes the people live inadequately, which is being studied (Bagheri, 2013; Isunju et al., 2011; Kamruzzaman \& Hakim, 2016; Latif et al., 2016; Simiyu, 2015) Slums are also vulnerable to violence, conflict, and crime (Becchetti et al., 2014; Datta, 2016; Felbab-Brown, 2011; LeBas, 2013; Parvin et al., 2016). Slum housing conditions cannot be separated from the series of problems that have been described in several previous studies. These various problems are faced by several cities in various countries, including Indonesia. Indonesia has a number of big cities with varying slum levels, one of which is Makassar.

Makassar City as one of the metropolitan cities in Indonesia has a slum area of 740.10 hectares, ranging from heavy, medium to low slums (SIAP, Document City Government, 2017). The Makassar City Government has developed and implemented various slum management programs, starting from poverty alleviation programs to more specific programs. Learning from the experience of slum eradication programs with various approaches that have been implemented is more likely to be assessed as a negative input variable. In this case, the slum area is seen as current well-being, not as future well-becoming. So that the slum area was better understand as an uninhabitable shelter. The basis for understanding this approach is that slums are solely based on spatial physical problems (spatial problem based), and the impact is that slum dwellers are considered passive victims of development. So that it seems to be a necessity for separation in the spatial system.

The phenomenon of slum areas of the Untia coastal area is a category of heavy slum areas with an area of 6.31 hectares based on the Decree of the Mayor of Makassar Number 826 / 653.2 / 2018 concerning the Revision and Verification of the Location of Slum Settlements in Makassar City. Slum typology is a coastal area with slum characteristics, including irregular residential buildings, damaged roads, unfulfilled drinking water needs, and poor sanitation. The condition of the Untia slum is influenced by the urbanization of immigrants from outside the region. The development of the city of Makassar and the strategic location of the area from the city borders and the Makassar Industrial Estate (MIE).

Base on the Table.1 the increasing complexity of the slum area problem in Makassar, especially the coastal slum area of Untia, shows that there are more and more handling programs being undertaken that involve many stakeholders. The result is an overlap between one institution and another, one actor with another, and one program with another. These problems have caused the handling of the Untia Makassar coastal slum area to face a dead-end. The Makassar City Government has made several arrangements for the slum area of the Untia coast but faces a dead end which seems to have ignored the condition of the Untia coastal slum area. 
Table.1 The Slum Distribution of Untia

\begin{tabular}{rccc} 
Location & Slum Area & Population & Population Density \\
\hline RT 001 RW 001 & 0.7 & 136 & 194 \\
RT 002 RW 001 & 0.8 & 146 & 182 \\
RT 003 RW 001 & 1.2 & 304 & 253 \\
RT 002 RW 002 & 0.4 & 97 & 242 \\
RT 003 RW 002 & 0.4 & 97 & 242 \\
RT 004 RW 002 & 0.5 & 71 & 142 \\
RT 001 RW 005 & 1.0 & 172 & 172 \\
RT 002 RW 005 & 1.0 & 213 & 213 \\
RT 003 RW 005 & 1.1 & 226 & 226 \\
& $\mathbf{7 . 1 3}$ & $\mathbf{1 4 6 2}$ & $\mathbf{2 0 6}$ \\
\hline
\end{tabular}

Source: (Prianto \& Amalia, 2019)

Therefore, the problem of dealing with slum settlements is analyzed using an advocacy coalition approach that is integrated with a collective action approach. The integration of these two approaches refers to Sabatier. Advocacy coalitions are consistently defined as people from various positions (officials and institutions) sharing a particular belief system that is a set of basic values, causal assumptions, and perceptions of problems and activities that are coordinated over time. In particular, collective action in the present advocacy coalition increases the likelihood that success will be sufficient to address common problems (Sabatier \& Weible, 2007).

\section{RESEARCH METHOD}

This article began from the results of research using a qualitative research approach. The data used in this study were obtained from interviews and reviews of documentation from several Makassar City government institutions: The Housing and Settlement Service; Public Works Service; Environmental services; Fire Department, Municipal Waterworks (PDAM) and Kotaku (City Without Slums) Makassar City. The six government agencies each have a role in managing the Untia coastal slum area of Makassar City with a different or the same focus.

The data obtained were then analyzed according to the theory used and interpreted to raise the fundamental substance behind the case under study. This data analysis is important to reveal both substantive and formal findings. Data analysis was an activity carried out to organize, sort, classify, code/mark, and categorize data to obtain findings that match the problem to be answered. The theory of advocacy coalitions which is integrated with collective action theory was used as a tool of analysis which becomes a reference for research using various forms of qualitative data. In the last stage, the researcher concluded the results of research on the findings in the field that have been processed based on the theory used.

\section{RESULT AND DICUSSION}

The results of in-depth interviews from several informants consisting of cross-agency shows that several factors trigger the presence of slum settlements in urban areas: the massive flow of population urbanization, the socio-economic conditions of the community, the sociocultural conditions of the community, and the natural physical characteristics of buildings. Various kinds of obstacles faced by the city government in order to create a city without slums. These constraints are the cause until now the Makassar City Government has not been able to create 0 percent slums as targeted in 2020. Including Untia is still categorized as one of the slum areas along with 126 other urban villages.

Based on the Table.2 Decree of the Mayor of Makassar on the Determination of Slum Settlements No. 050.05/1341/Kep/IX/2014 and No. 826/653.2/2018 Untia Urban is still in the heavy slum category. However, in 2019, Untia Urban Village has switched from heavy slum to light slum with an area of 3.31 hectares. Untia's housing quality improvement, which has improved slightly, is since several slum indicators are no longer met. 
Table.2 The slum level in Untia district 2019

\begin{tabular}{clc}
\hline No & \multicolumn{1}{c}{ Problem Indicator } & Volume \\
\hline 1 & Building Irregularities & 95 units \\
2 & Non-conformance with building technical requirements & 111 units \\
3 & No drainage is maintained & 1901 meters \\
4 & Incompatibility of fire protection facilities & 140 units \\
5 & Environmental road surface quality & 151 meters \\
\hline
\end{tabular}

Source: (Makassar Housing and Settelement Service, 2019)

\section{Unmatched Coalition}

The transition of Untia coastal status from a heavy slum to a light slum cannot be separated from the collective action of the relevant government agencies in this case: the Regional Development Planning Agency; Housing and Settlement Service; Regional Drinking Water Company (PDAM); Environmental services; Fire Department; and the Public Works Office; including Kotaku under the auspices of the Ministry of Public Works and Public Housing. These agencies are part of a team work to deal with slum areas in Makassar City, including the Untia coast.

Table. 3 explain, So many government agencies are involved in handling slum areas with different or the same roles and responsibilities. The size of the Team Work formed by the Makassar City government has not been able to help Untia become a slum-free area. Olson's thesis has analyzed this phenomenon first, that the larger the group size, the less likely the planned programs will be achieved. Slum management programs will be difficult to achieve if the agencies involved are too large. Overlapping interests between institutions will be difficult to avoid. However, some economic and political science models argue that institutions are only the result of individual exchanges (Adger, 2003). Individuals involved in a large group have the potential to become free riders for personal gain (Moreira et al., 2013; Olson, 2012; Ostrom, 2010).

Slum settlement policies that involve many agencies tend to be ineffective especially the potential presence of free riders in a large group. Therefore, in such conditions proposes a polycentric governance approach to the problem of collective action (Ostrom, 2008). Polycentric governance offers the opportunity to regulate not one, but multiple government agencies, with each of these units being able to exercise independent authority to make and enforce rules in a particular area. The main advantage of polycentric governance is that rules can be written in a general form which can then be adapted to local circumstances. In other words, more actions tailored to local needs can be authorized in polycentric governance structures than in monocentric structures that attempt to establish uniform rules for all regions.

The handling of the slum areas of Makassar City hardly involves non-formal actors outside the government. In the findings in the field, there is only one private party involved in assisting the Makassar City government through Corporate Social Responsibility (CSR) of 1 Billion Multigriya Financial Facility Company (SMF). Meanwhile, NGOs are not much involved in helping to plan and supervise the programs implemented by the government.

Whereas the formulation of policies in the policy-making process does not only involve the government unilaterally but also involves private sector actors and non-governmental organizations as an effort to develop standard criteria and indicators for a policy (Elliott \& Schlaepfer, 2001). The advocacy coalition approach is an institutional arrangement. This approach does not rigidly separate the domains of state, market and community institutions. The managed areas are considered to be interrelated and will therefore require a cohesive description and cooperation between the three groups of actors. As a medium to expand the political participation of state citizens in the public decision-making process, the existence of a coalition is legal and can be justified. This framework uses the belief system pattern as the focus of the mapping (Prianto, 2014).

The Makassar City Government in handling slum areas only formed a Team Work which involved several agencies and Kotaku. The ideal is in a program, it should involve the government, NGOs and the private sector both in planning and implementation. However, the minimal role of the two sectors outside of government indicates that the government is forming a coalition that 
will zero out. Groups with the same idea build alliances (pro) against groups that oppose their ideas (contra). To increase the power that influences in the policy formulation process, various groups with the same interests join together in the coalition. In the policy process, the advocacy coalition compromises actors from all policy subsystems. An advocacy coalition consists of actors from various institutions who share a set of policy beliefs.

The main pillar of decision making in the advocacy coalition approach is the policy subsystem. The policy subsystem consists of all parties that take part in the policy formulation process, including elements that can be differentiated based on existing beliefs and resources. These elements include: interest groups, bureaucrats and politicians, academics, researchers and other government actors. The framework for an advocacy coalition explains that policies are the product of oppression by multiple interests. In pluralist policy theory, power is not only in the hands of formal actors, but is also distributed among many groups, so that public policy is better understood as decisions made by many actors. The relationship between the two groups of actors is considered a reciprocal relationship that is often mediated by the existence of the brokerage group (Prianto, 2014).

The handling of slum areas by the Makassar City government in the advocacy coalition approach is to eliminate 2 important poles, namely policy brokers and coalitions outside the government. Coalitions outside of government are usually filled with NGOs which have a role to oversee the program's running or can even propose programs if the programs made by the government are not appropriate. Their existence is very important because it will provide input on how government policies are getting better by criticizing the government. Meanwhile, the existence of a policy broker has a central role, when 2 coalitions disagree with each other, they play a mediating role between the two. However, the two poles did not play a role or even do not exist in handling slum areas. This is what has cemented a coalition of unmatched government.

\section{Advocacy Coalitions: Collective Action as a Glue and Strategy}

The Makassar City Government continues to accelerate the handling of slum areas, one of which is through the City Without Slum (Kotaku) program. Kotaku program itself is one of the programs of the Directorate General of Human Settlements of the Ministry of Public Works and Public Housing (KemenPUPR) to accelerate the handling of slum settlements in Indonesia. The direction of the development policy is to build systems, facilitate local government, and facilitate communities. This program will tackle slum areas by building a collaborative platform through increasing the role of local government and participation from the community. Through this program, the Makassar City Government targets that in 2019 Makassar will be slum free as referred to in the National Medium-Term Development Plan (RPJMN) of 2015-2019.

Table.4 explain until now, Untia is still in the slum category even though several programs have been realized, both from the city government and the central government. But the Makassar Mayor's Slum Decree in 2014 and 2018 still places Untia Village as a heavy slum area. However, at the beginning of 2019, Untia Village had become a light slum area. This happened because Untia received many programs from the government for a relatively long time. This activity is a collaborative activity of several Makassar City and Kotaku government agencies. Improvement of environmental roads, drainage and access to clean water availability are the concerns of stakeholders who play a role in handling slums in Untia. In addition, several programs from the central government through the Special Allocation Fund (DAK), namely the Self-Help Housing Stimulus Assistance (BSPS) amounted to 17.5 million, with details of 5 million for material purchases and 2.5 million in the form of wages.

Several programs other than the above originate from the central government program for slum problems as well as several related elements: Urban Poverty Alleviation Program (P2KP), Community Self-Help Agency-Self-Help Groups (BKM-KSM), National Team for the Acceleration of Poverty Reduction (TNP2K). These programs proved unable to make Untia Village a slum-free area. Even with several programs that have been implemented, Untia's status has only changed from a heavy slum to a mild slum.

The inability to get out of the shadows of the slum was not due to a lack of assistance from the government, but rather the lack of integration of the programs implemented by the 
government. Slum area arrangement which involves many stakeholders with their respective duties should be to carry out program integration and concentrate on one area only. However, what happened in Untia and several slum areas in Makassar City was that they received different assistance at different times. In order to become a slum-free area, the model that must be done is program integration. This means that all budgeting for handling slum settlements is carried out for one residential area, so that all slum indicators can be addressed as a whole.

Based on the Table.5 The integration model referred to is to concentrate on handling slums in only one area by mobilizing all programs from each institution involved in the Team Work. The current government, and the period in the past, distributed different programs to each slum area in Makassar City. So, the result is that the settlements that receive the program only come out of the slum indicator partially. Apart from not integrating the slum management program which is a weakness, the institutions involved in the Team Work often overlap programs from each agency. "In 2019, we had programmed it, but when it was implemented, the Public Works Department also implemented the same program even though it was coordinated. In PU it is difficult to change the program because the APBD has been budgeted for, so Kotaku relented and moved to another location (Interview with Haerasdi, 2020).

Table.5 BDI PLPBK Regular Program 2018, Untia

\begin{tabular}{lcrr}
\hline KSM & Component Activities & Budget BDI PLPBK (Rp) & Public Budget (Rp) \\
Name & & & \\
\hline Bahari & Environmental Drainage & $19,180,000.00$ & 1.000 .000 .00 \\
& Paving Block Road & $477,520,000.00$ & 3.830 .000 .00 \\
Wisata & Environmental Drainage & $19,180,000.00$ & 1.250 .000 .00 \\
& Paving Block Road & $479,120,000.00$ & 4.730 .000 .00 \\
Amount & & $\mathbf{9 9 5 , 0 0 0 , 0 0 0 . 0 0}$ & $\mathbf{1 0 . 8 1 0 . 0 0 0 . 0 0}$ \\
BOP & & $\mathbf{5 , 0 0 0 , 0 0 0 . 0 0}$ & \\
Total & & $\mathbf{1 . 0 0 0 . 0 0 0 . 0 0 0 . 0 0}$ & \\
\hline
\end{tabular}

Source: (Kotaku, 2019)

Overlaps between programs and agencies still occur even though the division of work has been carried out based on the main tasks and functions of each agency. This indicates that the communication and intensity of meetings in the Team Work on slum handling have not been carried out intensively. Whereas better communication will increase collective action, and therefore, a coalition allows to solve problems and increase cooperation (Cardenas, 2003; Cardenas et al., 2011; Carpenter et al., 2004). The effectiveness of communication relates to the need for individuals in such social settings to express desires for one another so that they have to give up their interests for the benefit of the group. In other words, communication is used for "moral persuasion".

The intensity of face-to-face communication when discussing moral issues was much better than relying on written communication. General communication helps the group gain a sense of "solidarity" and face-to-face communication increases the likelihood that individuals will keep their promises to cooperate. In general, communication effectiveness appears to be related to the increase in trust that individuals gain when promises were made to them face-to-face (Ostrom, 2010). Lack of communication intensity in a large group reduces the sense of responsibility by the division of tasks that each has been assigned. This gap was then used by free riders to get individual benefits from the program being run. So, the policy will not run effectively and efficiently as planned.

\section{CONCLUSION}

This study found that in early 2019 , Untia had become a light slum area from previously heavy slums. This happened because Untia received many programs from the government (city and center) for a relatively long time. This activity is a collaborative activity of several government agencies of Makassar City and City Without Slum (Kotaku) who are members of the Team Work. Even so, Untia is still in the category of a slum area, not because of a lack of assistance 
from the government, but rather because the program is not integrated. So the result is the settlements that receive the program only partially out of several slum indicators. Apart from not integrating the slum management program, another weakness is that the institutions involved in the Working Group Team Work often overlap programs due to incomplete face-to-face communication.

\section{ACKNOWLEDGEMENT}

The author dedicates thank to the Directorate of Research and Community Service (DRPM), Ministry of Research and Technology / National Research and Innovation Agency for providing Research grants for Beginner Lecturers Decree Number: B / 87 / E3 / RA.00 / 2020 dated January 282020 and Agreement / Contract Number 4395 / LL9 / PG / 2020.

\section{REFERENCE}

Adger, W. N. (2003). Social capital, collective action, and adaptation to climate change. Economic Geography, 79(4), 387-404. https://doi.org/10.1111/j.1944-8287.2003.tb00220.x

Adubofour, K., Obiri-Danso, K., \& Quansah, C. (2013). Sanitation survey of two urban slum Muslim communities in the Kumasi metropolis, Ghana. Environment and Urbanization, 25(1), 189207. https://doi.org/10.1177/0956247812468255

Andini, I. (2013). Sikap dan Peran Pemerintah Kota Surabaya Terhadap Perbaikan Daerah Kumuh di Kelurahan Tanah Kalikedinding Kota Surabaya. Kebijakan Dan Manajemen Publik, 1(1), $36-47$.

Astuti, W. (2016). Community-Based Sanitation Program (Sanimas) As an Effort for Improving Environmental Quality in Urban Slum Settlements. Journal of Architecture\&ENVIRONMENT, 15(1), 11. https://doi.org/10.12962/j2355262x.v15i1.a2140

Bagheri, M. (2013). The Challenge of Slums: Socio-Economic Disparities. International Journal of Social Science and Humanity, 2(5), 410-414. https://doi.org/10.7763/ijssh.2012.v2.136

Bartz, A. (2001). Shelter from the storm. Industrial Fabric Products Review, 78(6), 32-34.

Becchetti, L., Conzo, P., \& Romeo, A. (2014). Violence, trust, and trustworthiness: Evidence from a Nairobi slum. Oxford Economic Papers, 66(1), 283-305. https://doi.org/10.1093/oep/gpt008

Bobhate, P. S. (2011). A Cross Sectional Study of Knowledge and Practices about Reproductive Health among Female Adolescents in An Urban Slum of Mumba. 5(4), 119-126.

Cardenas, J. C. (2003). Real wealth and experimental cooperation: Experiments in the field lab. Journal of Development Economics, 70(2), 263-289. https://doi.org/10.1016/S03043878(02)00098-6

Cardenas, J. C., Rodriguez, L. A., \& Johnson, N. (2011). Collective action for watershed management: Field experiments in Colombia and Kenya. Environment and Development Economics, 16(3), 275-303. https://doi.org/10.1017/S1355770X10000392

Carpenter, J. P., Daniere, A. G., \& Takahashi, L. M. (2004). Cooperation, trust, and social capital in Southeast Asian urban slums. Journal of Economic Behavior and Organization, 55(4 SPEC.ISS.), 533-551. https://doi.org/10.1016/j.jebo.2003.11.007

Datta, A. (2016). The intimate city: Violence, gender and ordinary life in Delhi slums. Urban Geography, 37(3), 323-342. https://doi.org/10.1080/02723638.2015.1096073

Elliott, C., \& Schlaepfer, R. (2001). The advocacy coalition framework: application to the policy process for the development of forest certification in Sweden. Journal of European Public Policy, 8(4), 642-661. https://doi.org/10.1080/13501760110064438

Felbab-Brown, V. (2011). Bringing the State to the Slum: Confronting Organized Crime and Urban 
Violence in Latin America. Lessons for Law Enforcement and Policymakers. Latin America Initiative at Brookings, December.

Gladstone, B. P., Das, A. R., Rehman, A. M., Jaffar, S., Estes, M. K., Muliyil, J., Kang, G., \& Bose, A. (2009). Burden of illness in the first 3 years of life in an Indian slum. Journal of Tropical Pediatrics, 56(4), 221-226. https://doi.org/10.1093/tropej/fmp116

Heston, Y. P., \& Yusuf A, A. (2013). PENGUATAN KEMAMPUAN SOSIAL PADA PENATAAN KAWASAN KUMUH PERKOTAAN (Studi Kasus Kelurahan Cigugur Tengah Cimahi). Jurnal Tataloka, 15(3), 208. https://doi.org/10.14710/tataloka.15.3.208-217

Isunju, J. B., Schwartz, K., Schouten, M. A., Johnson, W. P., \& van Dijk, M. P. (2011). Socio-Economic Aspects of Improved Sanitation in Slums: A review. Public Health, 125(6), 368-376. https://doi.org/10.1016/j.puhe.2011.03.008

Kamruzzaman, M., \& Hakim, M. A. (2016). Socio-economic Status of Slum Dwellers: An Empirical Study on the Capital City of Bangladesh. American Journal of Business and Society, 1(2), 1318. http://www.aiscience.org/journal/ajbs

Kandusu, F., Miswan, M., \& Yani, A. (2019). Gambaran Kondisi Sanitasi Lingkungan Pada Kawasan Kumuh Di Kelurahan Ujuna Kecamatan Palu Barat. Jurnal Kolaboratif Sains, 1(1), 1-9.

Katukiza, A. Y., Ronteltap, M., Niwagaba, C. B., Foppen, J. W. A., Kansiime, F., \& Lens, P. N. L. (2012). Sustainable sanitation technology options for urban slums. Biotechnology Advances, 30(5), 964-978. https://doi.org/10.1016/j.biotechadv.2012.02.007

Katukiza, A. Y., Ronteltap, M., Oleja, A., Niwagaba, C. B., Kansiime, F., \& Lens, P. N. L. (2010). Selection of sustainable sanitation technologies for urban slums - A case of Bwaise III in Kampala, Uganda. Science of the Total Environment, 409(1), 52-62. https://doi.org/10.1016/j.scitotenv.2010.09.032

Kotaku. (2019). Untia Village Collaboration Program Implementation Report.

Kulkarni, M., Durge, P., \& Kasturwar, N. (2012). Prevalence of anemia among adolescent girls in an urban slum. National Journal of Community Medicine, 3(1), 108-111.

Latif, M. B., Irin, A., \& Ferdaus, J. (2016). Socio-Economic and Health Status of Slum Dwellers of The Kalyanpur Slum in Dhaka City. Bangladesh Journal of Scientific Research, 29(1), 73-83. https://doi.org/10.3329/bjsr.v29i1.29760

LeBas, A. (2013). Violence and Urban Order in Nairobi, Kenya and Lagos, Nigeria. Studies in Comparative International Development, 48(3), 240-262. https://doi.org/10.1007/s12116-013-9134-y

Makassar Housing and Settelement Service. (2019). Untia Village Slum Report.

Mardhanie, A. B. (2013). Penelitian Pemetaan Kawasan Kumuh Permukiman Kecamatan Tanjung Selor - Kabupaten Bulungan. Jurnal Inersia, V(1), 1-8.

Moreira, J. A., Pacheco, J. M., \& Santos, F. C. (2013). Evolution of collective action in adaptive social structures. Scientific Reports, 3, 1-6. https://doi.org/10.1038/srep01521

Nakamura, S. (2014). Impact of slum formalization on self-help housing construction: A case of slum notification in India. Urban Studies, 51(16), 3420-3444. https://doi.org/10.1177/0042098013519139

Nakamura, S. (2017). Does slum formalisation without title provision stimulate housing improvement? A case of slum declaration in Pune, India. Urban Studies, 54(7), 1715-1735.

Oli, N., Vaidya, A., \& Thapa, G. (2013). Behavioural Risk Factors of Noncommunicable Diseases among Nepalese Urban Poor: A Descriptive Study from a Slum Area of Kathmandu. Epidemiology Research International, 2013, 1-13. https://doi.org/10.1155/2013/329156 
Olson, M. (2012). Mancur Olson - Logic of Collective Action.

Omole, K. F. (2010). An Assessment of Housing Condition and Socio-Economic Life Styles of Slum Dwellers in Akure, Nigeria. Contemporary Management Research, 6(4), 273-290. https://doi.org/10.7903/cmr.2980

Ostrom, E. (2008). UNDP. Polycentric Systems as One Approach for Solving Collective-Action Problems, 2008(11), 02. https://doi.org/10.2139/ssrn.1936061

Ostrom, E. (2010). Analyzing collective action. Agricultural Economics, 41(SUPPL. 1), 155-166. https://doi.org/10.1111/j.1574-0862.2010.00497.x

Parvin, K., Sultana, N., \& Naved, R. T. (2016). Disclosure and help seeking behavior of women exposed to physical spousal violence in Dhaka slums. BMC Public Health, 16(1), 1-8. https://doi.org/10.1186/s12889-016-3060-7

Peters, B. G., \& Pierre, J. (2012). Urban Governance. The Oxford Handbook of Urban Politics, November. https://doi.org/10.1093/oxfordhb/9780195367867.013.0005

Prianto, A. L. (2014). Model of Advocacy Coalitions in the Formulation of Spatial Plan Policy of Makassar in 2010-2030. Bisnis \& Birokrasi Journal, 20(3). https://doi.org/10.20476/jbb.v20i3.3205

Prianto, A. L., \& Amalia, A. A. (2019). Combatting Slums, Suistaining Poverty: Dynamic Urban Governance in Makassar, Indonesia. Otoritas: Jurnal Ilmu Pemerintahan, 9(1), 28-41. https://doi.org/10.20476/jbb.v20i3.3205

Sabatier, P. A., \& Weible, C. M. (2007). The Advocacy Coalition Framework Innovations and Clarifications. In Theories of the Policy Process. Theories of The Policiy Process. http://www.informaworld.com/10.1080/01402380701239921\%0Awww.ksherif.com/i mages/Lecture_10-Comparison_of_Frameworks.ppt

Sengupta, P., Philip, N., \& Benjamin, A. I. (2010). Epidemiological correlates of under-nutrition in under-5 years children in an urban slum of Ludhiana. Health and Population: Perspectives and Issues, 33(1), 1-9.

Simiyu, S. (2015). Socio-Economic Dynamics in Slums and Implications for Sanitation Sustainability in Kisumu, Kenya. Development in Practice, 25(7), 986-996. https://doi.org/10.1080/09614524.2015.1073223

Siregar, T. J. (2010). Kepedulian Masyarakat Dalam Perbaikan Sanitasi Lingkungan Permukiman Kumuh di Kelurahan Matahalasan Kota Tanjungbalai. Pembangunan Wilayah Dan Kota.

Suprijanto, I. (2005). Karakteristik Spesifik, Permasalahan Dan Potensi Pengembangan Kawasan Kota Tepi Laut/Pantai (Coastal City) Di Indonesia. Jurnal Geomatika., 1, 15-16.

UN-DESA (United Nations, D. of E. and S. A. (2014). World Urbanization Prospects. United Nation. https://doi.org/http://dx.doi.org/10.4054/DemRes. 2005.12.9

Van Dijk, M. P., Etajak, S., Mwalwega, B., \& Ssempebwa, J. (2014). Financing sanitation and cost recovery in the slums of Dar es Salaam and Kampala. Habitat International, 43, 206-213. https://doi.org/10.1016/j.habitatint.2014.02.003

Vinod, N., Swarnakanta, L., Smita, P., \& Pushpa, D. (2011). Nutritional Status and Dietary Pattern O f Under Five Children In Urban Slum Area. National Journal of Community Medicine, 2(1), 143-148. 
Table.3 Slum Treatment Division of Work

\begin{tabular}{|c|c|c|c|}
\hline No & Slum criteria & Indicator & Relevant agencies \\
\hline 1 & Building & $\begin{array}{l}\text { 1. Irregularity of the building } \\
\text { 2. The level of building density that does } \\
\text { not meet the RT/RW } \\
\text { 3. Building quality: environmental } \\
\text { impact control; buildings above or } \\
\text { below ground/water; safety, health, } \\
\text { comfort and ease of building, }\end{array}$ & $\begin{array}{l}\text { Housing and } \\
\text { Settlement Service }\end{array}$ \\
\hline 2 & Environment & $\begin{array}{l}\text { 1. a road environment that does not fill } \\
\text { all settlements } \\
\text { 2. Bad road surface }\end{array}$ & $\begin{array}{l}\text { Public Works Service; } \\
\text { and The Housing and } \\
\text { Settlement Service }\end{array}$ \\
\hline 3 & $\begin{array}{l}\text { Provision } \\
\text { Drinking Water }\end{array}$ & $\begin{array}{l}\text { 1. Unavailability of safe access to } \\
\text { drinking water } \\
\text { 2. Drinking water needs are not met }\end{array}$ & $\begin{array}{l}\text { Municipal Waterworks } \\
\text { (PDAM) }\end{array}$ \\
\hline 4 & $\begin{array}{l}\text { Environmental } \\
\text { Drainage }\end{array}$ & $\begin{array}{l}\text { 1. Uncompressible drainage } \\
\text { 2. Unavailability of drainage } \\
\text { 3. Not connected to the urban drainage } \\
\text { system } \\
\text { 4. Not maintained } \\
\text { 5. Poor quality of drainage }\end{array}$ & Public Works Service \\
\hline 5 & $\begin{array}{l}\text { Wastewater } \\
\text { Management }\end{array}$ & $\begin{array}{l}\text { 1. Wastewater management system does } \\
\text { not comply with technical standards } \\
\text { 2. Facilities and infrastructure that do } \\
\text { not comply with technical standards }\end{array}$ & $\begin{array}{l}\text { Environmental } \\
\text { Services }\end{array}$ \\
\hline 6 & $\begin{array}{l}\text { Solid Waste } \\
\text { Management }\end{array}$ & $\begin{array}{l}\text { 1. Facilities and infrastructure that do } \\
\text { not comply with technical standards } \\
\text { 2. Solid waste management system does } \\
\text { not comply with technical standards: } \\
\text { container and domestic sorting, } \\
\text { collection, transportation and } \\
\text { environmental processing } \\
\text { 3. Unmaintained }\end{array}$ & $\begin{array}{l}\text { Environmental } \\
\text { Services }\end{array}$ \\
\hline 7 & Fire Protection & $\begin{array}{l}\text { 1. Unavailability of fire protection } \\
\text { infrastructure: water supply, } \\
\text { environmental roads, and means of } \\
\text { communication } \\
\text { 2. Unavailability of fire protection } \\
\text { facilities: light fire extinguishers } \\
\text { (APAR), fire engines, and staircases }\end{array}$ & Fire Department \\
\hline
\end{tabular}


Table.4 The Collaboration of Untia Slum Management Program in 2017 \& 2018

\begin{tabular}{lcllcc}
\hline Years & $\begin{array}{c}\text { Location } \\
\text { Activities }\end{array}$ & \multicolumn{1}{c}{ Component Activities } & $\begin{array}{c}\text { Directorate PKP } \\
\text { (Rp) }\end{array}$ & $\begin{array}{c}\text { APBD city of } \\
\text { Makassar (Rp) }\end{array}$ \\
\hline 2017 & RT002-RW001 & Environmental Drainage & - & $105,000,000.00$ \\
& RT002-RW002 & Concrete Road & - & $200,000,000.00$ \\
2018 & Paving Block Road & - & $125,000,000.00$ \\
& RT001-RW001 & Paving Block Road & $445,980,000.00$ & - \\
& RT001-RW005 & Paving Block Road & $449,780,000.00$ & - \\
& RT002-RW001 & Paving Block Road & $475,411,000.00$ & - \\
& RT002-RW002 & Divider Tube & $290,860,000.00$ & - \\
& & Environmental Drainage & $23,760,000.00$ & - \\
& & Paving Block Road & $426,980,000.00$ & - \\
& RT002-RW005 & Environmental Drainage & $32,400,000.00$ & - \\
& & Paving Block Road & $624,200,000.00$ & - \\
& RT003-RW001 & Paving Block Road & $603,775,000.00$ & - \\
RT003-RW002 & Paving Block Road & $587,150,000.00$ & - \\
RT003-RW005 & Environmental Drainage & $90,720,000.00$ & - \\
& Paving Block Road & $447,289,000.00$ & - \\
& RT004-RW002 & Environmental Drainage & $74,160,000.00$ & - \\
& Paving Block Road & $624,200,000.00$ & - \\
Total & & $\mathbf{5 , 1 9 6 , 6 6 5 , 0 0 0 . 0 0}$ & $\mathbf{4 3 0 , 0 0 0 , 0 0 0 . 0 0}$ \\
\hline
\end{tabular}

Source: (Kotaku, 2019) 